\title{
Intussusceptions as acute abdomen caused by Burkitt lymphoma: a case report Faton T Hoxha* ${ }^{1,2}$, Shemsedin I Hashani ${ }^{1,2}$, Avdyl S Krasniqi ${ }^{1,2}$, Fisnik I Kurshumliu ${ }^{1,2}$, Driton S Komoni ${ }^{1}$, Shpresa M Hasimja ${ }^{1}$ and Mehmet Maxhuni ${ }^{1,2}$
} \author{
Prishtina, Mother Theresa str pn, Prishtina 10000, Republic of Kosovo \\ E-mail: Faton T Hoxha* - faton_an@yahoo.com; Shemsedin I Hashani - shemihashani@gmail.com; \\ Avdyl S Krasniqi - dr_krasniqi2001@yahoo.com; Fisnik I Kurshumliu - fkurshumliu@yahoo.com; \\ Driton S Komoni - dritonkomoni@hotmail.com; Shpresa M Hasimja - shpresa_hasimja@yahoo.com; \\ Mehmet Maxhuni - mehmetmaxhuni@yahoo.com \\ ${ }^{*}$ Corresponding author
}

Addresses: ${ }^{1}$ University Clinical Centre of Kosova, Rrethi Spitalit str p n, Prishtina 10000, Republic of Kosovo and ${ }^{2}$ Medical Faculty, University of

Published: 14 December 2009

Cases Journal 2009, 2:9322 doi: 10.1186/1757-1626-2-9322

This article is available from: http://www.casesjournal.com/content/2/1/9322

(C) 2009 Hoxha et al; licensee BioMed Central Ltd.

This is an Open Access article distributed under the terms of the Creative Commons Attribution License (http://creativecommons.org/licenses/by/2.0), which permits unrestricted use, distribution, and reproduction in any medium, provided the original work is properly cited.

\begin{abstract}
Introduction: Burkitt's lymphoma is a highly malignant, aggressive and rapidly growing B-cell neoplasm, which has low long-term survival rates. The abdomen is the most frequent onset site of non endemic Burkitt's lymphoma. Symptoms are often misleading and make diagnosis difficult. lleum intussusception as acute abdomen caused by Burkitt lymphoma is rare.

Case presentation: We are presenting a case of a 16 year-old male with acute abdomen, which three weeks prior initially has been surgically treated for acute appendicitis and Meckel diverticulitis. Following this was a second urgent operation of ileoileal intusussception caused by Burkitt lymphoma. Right extended haemicolectomy was performed.
\end{abstract}

Conclusion: Affected terminal ileum by Burkitt's lymphoma may mimic clinically acute appendicitis and investigation tools sometimes may not provide proper diagnosis.

Complete resection results in improved survival.

\section{Introduction}

First described by Dennis Burkitt in 1958, Burkitt lymphoma (BL) is a highly aggressive non-Hodgkin lymphoma (NHL) often presenting in extra nodal sites or as an acute leukemia [1].

Three variants have been described: endemic (largely found in Africa), sporadic (non-endemic) subsequently described outside Africa, affecting mainly abdominal viscera and third variant, immunodeficient patients.
Burkitt's lymphoma is usually diagnosed in children and young adults, and to a lesser extent in middle aged adults. BL is a B-cell lymphoma genetically characterized by a chromosomal translocation that results in deregulation of the c-MYC oncogene [2-4].

In endemic areas, usually involves the facial bones, particularly the jaw, maxilla, and orbit, especially in young children, associated with Epstein-Barr virus (EBV) infection, as well as frequent concomitant malaria infection $[5,6]$. 
In comparison, the sporadic form tends to present in the lymphoid tissues of the gut, often presenting as masses in the Waldeyer ring or the terminal ileum, or even with involvement of abdominal organs with the most involvement of the distal ileum, caecum or mesentery. Bone marrow involvement is commonly seen in progressive disease [6-8].

\section{Case presentation}

We are presenting a case with acute abdomen, i.e. ileoileal intusussception, caused by Burkitt lymphoma. A sixteen-year-old Caucasian Kosovar boy, presented in the surgical emergency clinic as acute abdomen, with abdominal pain, nausea, vomiting, and problems with defecation and flatulence. The symptoms started three days ago, worsening on admission day.

The patient's height was $178 \mathrm{~cm}$, and his weight was $70 \mathrm{~kg}$. His vital signs were: blood pressure 120/80 mmHg; pulse rate: 76 beats/min; respiratory rate $20 / \mathrm{min}$; body temperature $37.1^{\circ} \mathrm{C}$.

During physical examination, a distended, diffusely tender and painful abdomen with lower abdomen rebound was revealed. The patient's skin was pale with sweats.

Plane abdominal radiography showed mechanical obstruction (Fig. 1).

The emergency laboratory tests presented as follows: Red blood cells (RBC): $4.61 \times 10^{9} / \mathrm{L}$; white blood cells (WBC): $7.3 \times 10^{9} / \mathrm{L}$; Hemoglobin (Hgb): $128 \mathrm{~g} / \mathrm{L} ;$ Hematocrit (Htc): 0.42; blood sugar: $5.42 \mathrm{mmol} / \mathrm{L}$; blood urea nitrogen (BUN): $2.6 \mathrm{mmol} / \mathrm{L}$; serum creatinine: $88 \mu \mathrm{mol} / \mathrm{L}$; BUN/ Creat ratio: 8.5; total protein: $72 \mathrm{~g} / \mathrm{L}$; albumin: $36 \mathrm{~g} / \mathrm{l}$; ALP: 60 IU/L; ALT: $26 \mathrm{IU} / \mathrm{L} ;$ AST:40 IU/L; direct bilirubin: $5.8 \mu \mathrm{mol} / \mathrm{L}$; total bilirubin: $20.5 \mu \mathrm{mol} / \mathrm{L}$; indirect bilirubin: $14.7 \mu \mathrm{mol} / \mathrm{L}$; Gama GT: $26 \mathrm{IU} / \mathrm{L}$; C-reactive protein: $15.6 \mathrm{mg} / \mathrm{L}$; serum amylase: $30 \mathrm{U} / \mathrm{L}$ : electrolytes: $\mathrm{Na}$ : $138 \mathrm{mmol} / \mathrm{L} ; \mathrm{K}: 3.75 \mathrm{mmol} / \mathrm{L} ; \mathrm{Cl}: 102 \mathrm{mmol} / \mathrm{L}$; urinalysis: 2-4 Leucocytes, some bacteria and some uric acid crystals. Blood group: O Rh(D) poz.

Three weeks prior he had been surgically treated as acute abdomen caused by acute appendicitis and Mckelly Diverticulitis. Appendectomy and short resection of the ileum with diverticulum, and end-to-end anastomosis was performed. The immediate post operative period went well. After his discharge, his second hospital admission was two weeks after operation with abdominal pain and constipation problems which released spontaneously after two days.

At his third admission as acute abdomen, urgent laparotomy was performed in general endo tracheal

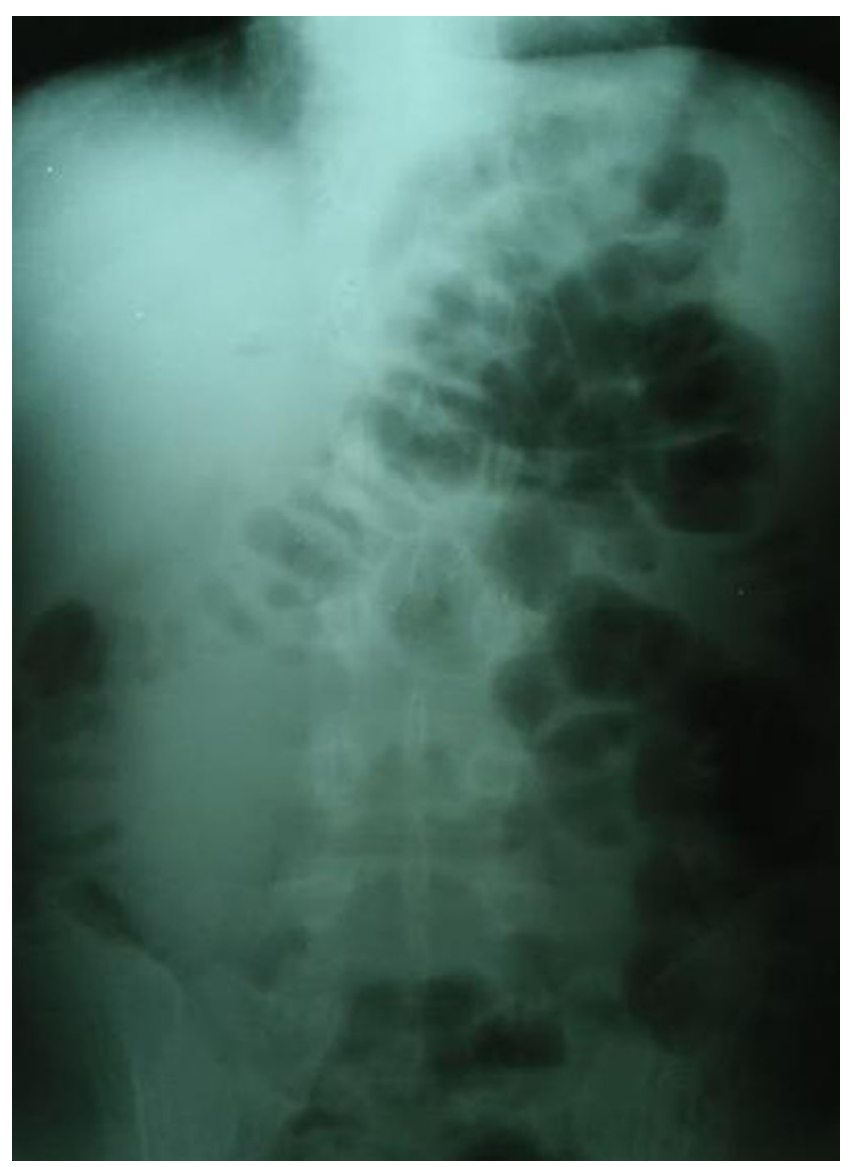

Figure I

Abdominal native radiography.

anesthesia on the day after admission. Intra operative findings revealed small bowel dilatation, with intussusceptions of the terminal ileum, $2 \mathrm{~cm}$ from ileocecac valve. There were multiple enlarged mesenteric lymph nodes at the meso of the terminal ileum, ascending and the transverse colon, without palpable liver metastases.

We have done des intussusceptions caused by tumor from the wall of the ileum (Fig. 2, 3, 4).

Adhesions at the anastomosis, and $60 \mathrm{~cm}$ above that, were released. The right extended haemicolectomy with end to end ileum-transverse anastomosis was performed. Post operative period went well; blood pressure was 120/80 $\mathrm{mmHg}$, pulse rate beats: $65 / \mathrm{min}$; temp.: $36.7^{\circ} \mathrm{C}$. The wound healed per primam. He was treated with frozen fresh plasma (several doses-seven), red blood cells (one dose); antibiotic, analgesics, H2 blockers, vitamins, amino acids, human albumins. He was discharged on the $10^{\text {th }}$ postoperative days, with good bowel movements. He was oriented to the Hematology Department for further treatment, for Burkitt Lymphoma with chemotherapy. 


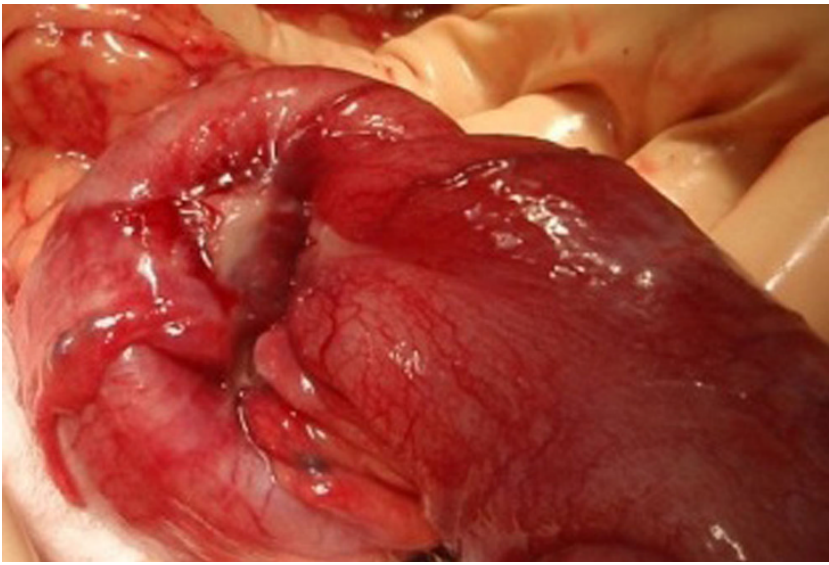

Figure 2

Terminal ileum intussusception caused by Burkitt lymphoma.

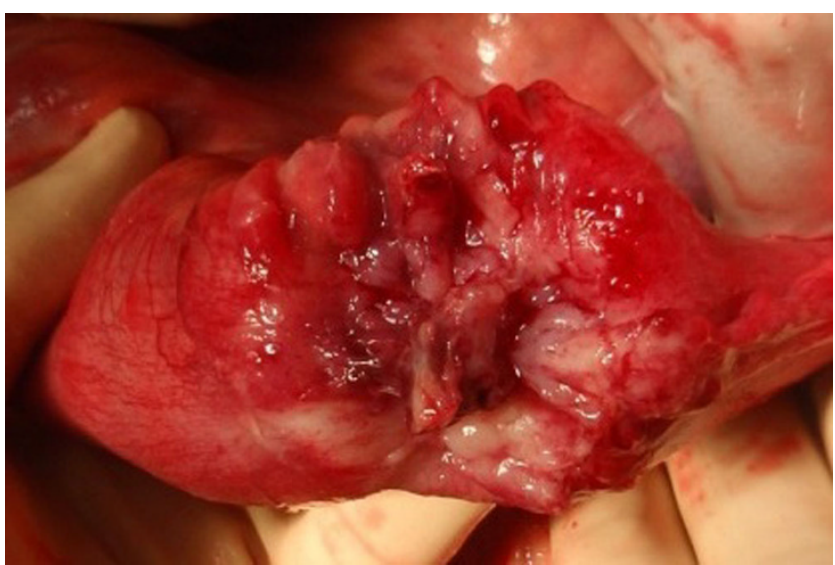

Figure 3

Des intussusception of terminal ileum with Burkitt Lymphoma.

HP opinion: Giemsa staining demonstrated neoplastic lymphocytes infiltration. Immunochemical testing was positive for Burkitt lymphoma (CD10, CD20, CD34, Bcl-2, Ki67, IgM, MIB-1 with a proliferation index of over $90 \%$ of neoplastic cells) and c-myc translocation determined by FISH analysis (fusion and split) (Fig. 5, $6,7,8,9)$.

\section{Discussion}

Sporadic Burkitt's lymphoma accounts for 1\%-2\% of lymphoma in adults and up to $40 \%$ of lymphoma in children in the United States and Western Europe [2].

Estimated incidence ranges from one case per million for children less than ten years old, 0.7 per million from 10

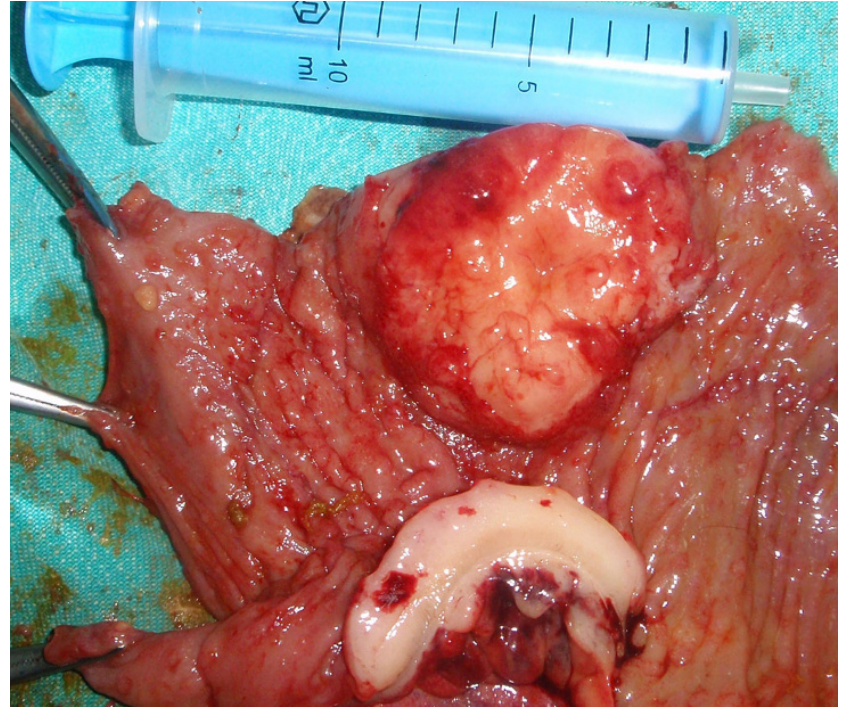

Figure 4

Macroscopic view of opened terminal ileum and Burkitt lymphoma.

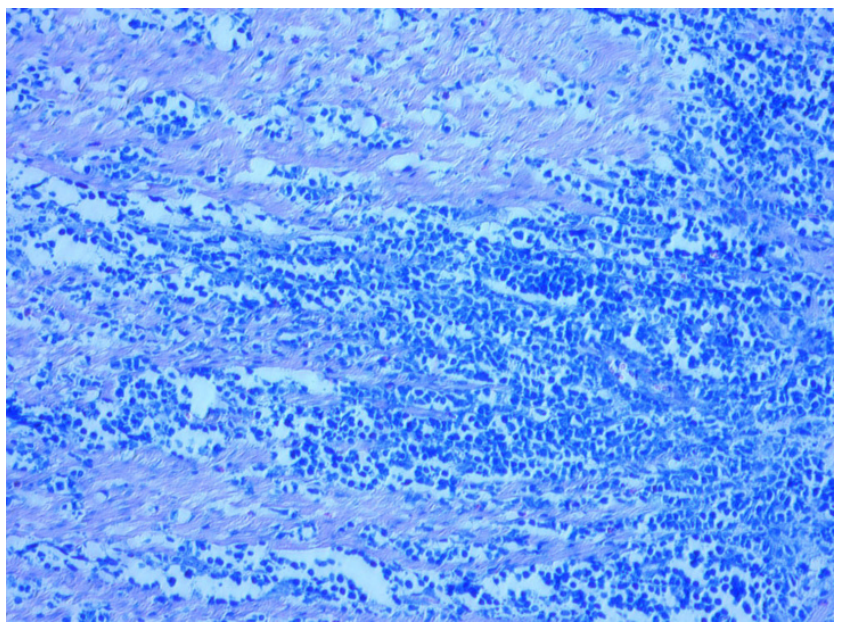

Figure 5

Solid sheets of medium sized neoplastic lymphocytes infiltrating between layers of muscularis propria (×I0; Giemsa stain).

to 20 and 0.6 per million from 20 to 30 , and rare in patients older than $30[9,10]$.

Burkitt's lymphoma is an aggressive, highly malignant and rapidly growing B-cell neoplasm frequently presenting onset in the abdomen in non-endemic Burkitt's lymphoma regions. Intussusception caused by Burkitt lymphoma, as a cause of acute abdomen, is rare, with 


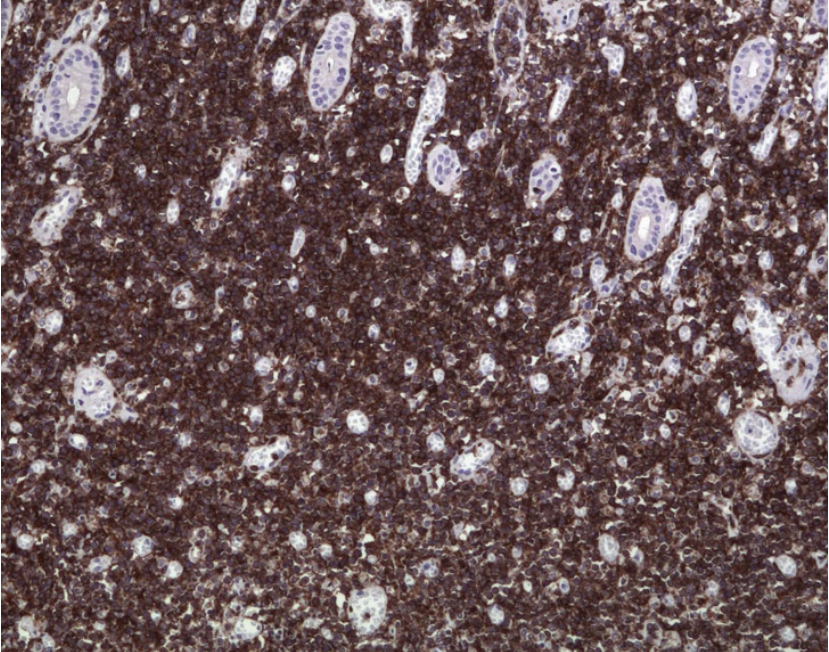

Figure 6

Pronounced membranous immunoreactivity for CDIO of the neoplastic B-cells $(\times 20$; Immunoperoxidase).

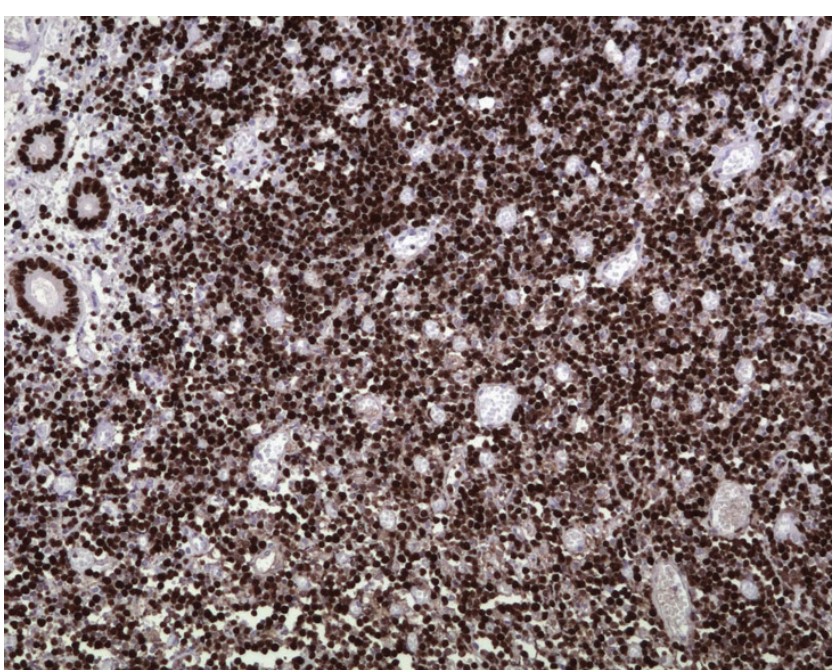

Figure 7

A proliferation index of over $90 \%$ of neoplastic cells as determined by MIB-I immunohistochemistry ( $\times 10$; Immunoperoxidase).

symptoms which often mislead and make diagnosis more difficult [11].

The rapidity of volumetric doubling of this neoplasm frequently justifies an acute abdomen presentation that may mime other less-rare diseases $[6,11]$.

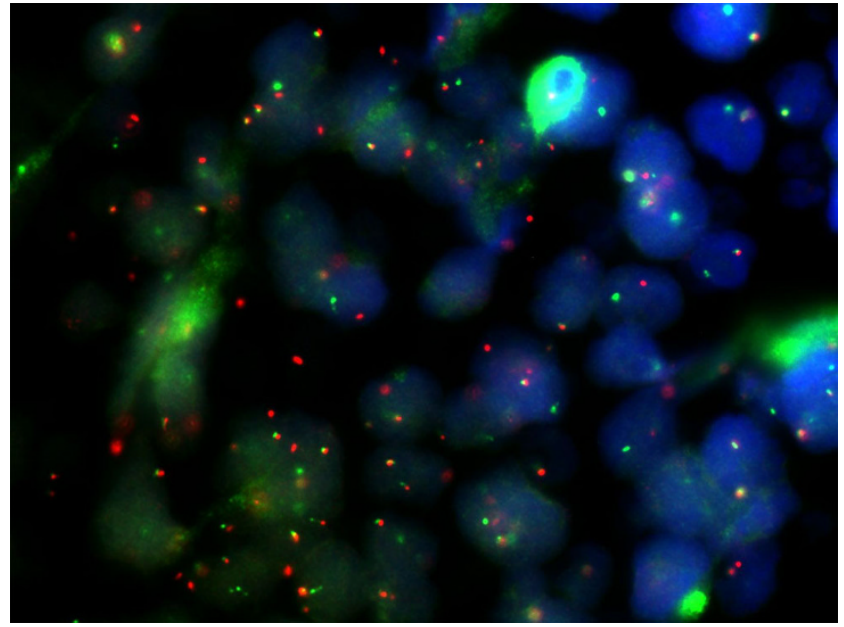

Figure 8

c-myc translocation as determined by FISH analysis (fusion).

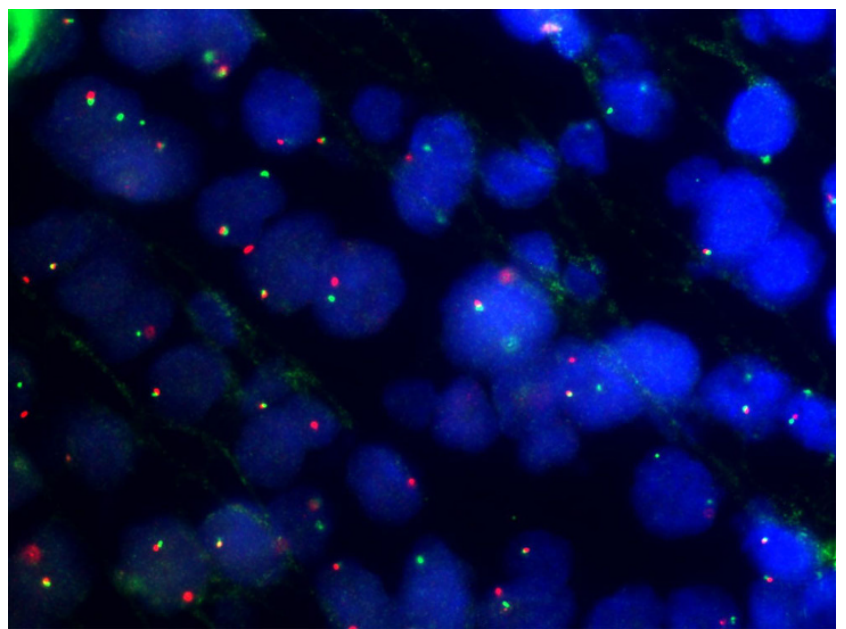

Figure 9

c-myc translocation as determined by FISH analysis (split).

The clinical presentation on undiagnosed Burkitt lymphoma is very non-specific, which makes this a difficult condition to diagnose.

The sporadic form commonly presents with abdominal swelling as a large mesenteric, retroperitoneal or pelvic mass, tenderness, pain or fullness. Some patients present with symptoms of bowel obstruction secondary to ileocaecal intussusception caused by tumor growth, obstruction or bleeding, mimicking acute appendicitis $[6,10]$. 
Our patient had a clinical presentation of acute abdomen, with abdominal pain, distended abdomen, vomiting, and no flatulence with intestinal obstruction.

Burkitt's lymphoma is more common in males than females [10,12-15].

In reviews that includes significant numbers of adult patients with abdominal Burkitt's lymphoma, about $33 \%$ to $50 \%$ of the patients were older than $20[10,15]$.

Magrath's review included $97 \%$ patients younger than 15 [16].

Burkitt's lymphoma occurring in adults, involving the terminal ileum with ileal or ileocolic intussusception's has been reported as acute abdomen required an emergency surgery reported as case or as small numbers in series, treated with small bowel resection or right haemicolectomy $[10,11,14,15,17-19]$.

Our case presentation is the first case of Burkitt's lymphoma with abdominal involvement, causing ileoileal intussusception, diagnosed and treated with extensive surgical resection here in Kosova.

Surgery is required in the treatment of Burkitt's lymphoma to confirm the diagnosis and to relieve the common presenting symptoms of intestinal obstruction, abdominal mass, intussusception, or acute abdomen. Complete resection is associated with improved survival.

Some reports demonstrated higher survival rate $58 \%$ $89 \%$ ) in patients having extensive surgical resection versus for patients having only partial or incomplete resection (40\%-45\%) at 2-5 years [[10,15], and [16]].

However, this may merely reflect the fact that less disease is more easily completely resected [20].

These authors broadened the role of surgery by suggesting that, even in patients with disseminated disease, the surgeon plays an important role in the secondary management of the disease.

\section{Conclusion}

Affected terminal ileum by Burkitt's lymphoma may mimic clinically acute appendicitis and investigative tools sometimes may not provide proper diagnosis.

Complete resection results in an improved patient survival.

\section{Patient's perspective}

Symptoms like abdominal pain, nausea, vomiting, and problems with defecation and flatulence they started three days ago, worsening on admission day in Hospital. My skin was pale and sweats. During physical examination, my belly was distended, diffusely tender and painful. Plane abdominal radiography showed mechanical obstruction.

Three weeks prior I had been surgically treated as acute abdomen caused by acute appendicitis and Mckelly Diverticulitis. Appendectomy and short resection of the ileum with diverticulum, and end-to-end anastomosis was performed. The immediate post operative period went well. After discharge, my second hospital admission was two weeks after operation with abdominal pain and constipation problems which released spontaneously after two days.

At my third admission as acute abdomen, urgent laparotomy was performed in general endo tracheal anesthesia on the day after admission.

The right extended haemicolectomy with end to end ileum-transverse anastomosis was performed. Post operative period went well; the wound healed per primam. I was discharged on the $10^{\text {th }}$ postoperative days, with good bowel movements, and oriented to the Hematology Department for further treatment, for Burkitt Lymphoma with chemotherapy.

Burkitt's lymphoma as sporadic form, and very rare in our country affecting abdomen in children and young adults, with extensive surgery and chemotherapy gives a good hope for the future of this patients.

\section{Consent}

Written informed consent was obtained from the patient for publication of this case report and accompanying images. A copy of the written consent is available for review by the Editor-in-Chief of this journal.

\section{Competing interests}

The authors declare that they have no competing interests.

\section{Authors' contributions}

FTH, SHIH, DSK and SHIH performed the surgery and the general anesthesia.

FIK has made Histopathology. FTH designed the work, the other authors contributed equally to this work.

\section{References}

I. Burkitt $D$ : A sarcoma involving the jaws in African children. $\mathrm{Br}$ J Surg 1958, 46, 197:218-223.

2. Blum KA, Lozanski G and Byrd JC: Adult Burkitt leukemia and lymphoma. Blood 2004, 104(10):3009-20, Epub 2004 Jul 20. 
3. Jaffe ES, Harris NL, Stein H, Vardiman JW and editors: Pathology and Genetics of Tumours of Haematopoietic and Lymphoid Tissues. World Health Organization Classification of Tumours Lyon: IARC Press; 200I.

4. Orem J. Mbidde EK and Weiderpass E: Current investigations and treatment of Burkitt's lymphoma in Africa. Tropical Doctor 2008, 38:7-1I.

5. McNally RJ and Parker L: Environmental factors and childhood acute leukemias and lymphomas. Leuk Lymphoma 2006, 47:583-598.

6. Biswas S: Report Of A Case Of Abdominal Burkitt's Lymphoma Presenting As Localized Right lliac Fossa Pain Mimicking Acute Appendicitis. The Internet Journal of Surgery ${ }^{\text {TM }}$ ISSN: 1528-8242. The Internet Journal of Surgery 2007, 9(I).

7. Yustein IT and Dang CV: Biology and treatment of Burkitt's lymphoma. Curr Opin Hematol 2007, I4:375-38I.

8. Musallam KM, Taher AT and Shamseddine Al: Burkitt's lymphoma of the colon and bronchi: three case reports. Cases J 2008, I(I): 15 .

9. Levine PH, Kamaraju LS, Connelly RR, Berard CW, Dorfman RF, Magrath I and Easton JM: The American Burkitt's Lymphoma Registry: eight years' experience. Cancer 1982, 49:1016-22.

10. McClenathan JH: Burkitt's Lymphoma of the Abdomen: The Northern California Kaiser Permanente Experience. The Internet Journal of Surgery 2009, I 8(2).

II. Cossaro M, Noce L, Bonutti A, Pecile P Di Loreto C, Saro F, Intini S and Terrosu G: An abdominal Burkitt's lymphoma in acute phase. Case report. Minerva Pediatr 2006, 58(3):3। I-8.

12. Stein JE, Schwenn MR, Jacir NN and Harris $\mathrm{BH}$ : Surgical restraint in Burkitt's lymphoma in children. J Pediatr Surg I99I, 26(II): 1273-5.

13. Kaufman BH, Burgert EO Jr and Banks PM: Abdominal Burkitt's lymphoma: role of early aggressive surgery. J Pediatr Surg 1987, 22(7):67I-4.

14. Zinzani PL, Magagnoli M, Pagliani G, Bendandi M, Gherlinzoni F, Merla E, Salvucci M and Tura S: Primary intestinal lymphoma: Clinical and therapeutic features of 32 patients. Haematologica 1997, 82:305-308.

15. Kemeny MM, Magrath IT and Brennan MF: The role of surgery in the management of American Burkitt's lymphoma and its treatment. Ann Surg 1982, 196(1):82-6.

16. Magrath IT, Lwanga S, Carswell W and Harrison N: Surgical Reduction of Tumour Bulk in Management of Abdominal Burkitt's Lymphoma. British Medical Journal I 974, 2:308-3I2.

17. Choung SR, Jeen TY, Kim SY and Hur WB: A Case of Small Intestinal Burkitt's Lymphoma in an Adult. Korean J Gastrointest Endosc 200I, 22:435-439.

18. Marinis A, Yiallourou A, Samanides L, Dafnios N, Anastasopoulos G Vassiliou I and Theodosopoulos T: Intussusception of the bowe in adults: A review. World | Gastroenterol 2009, I5(4):407-4 I I.

19. Stovroff MC, Coran AG and Hutchinson RJ: The Role of Surgery in American Burkitt's Lymphoma in Children. J Pediatr Surg | $99 \mid, 26(10): 1235-8$.

20. Arseneau JC, Canellos GP, Banks PM, Berard CW, Gralnick HR and DeVita VT Jr: American Burkitt's lymphoma: a clinicopathologic study of 30 cases. I. Clinical factors relating to prolonged survival. Am J Med I975, 58(3):3|4-2| .
Publish with BioMed Central and every scientist can read your work free of charge

"BioMed Central will be the most significant development for disseminating the results of biomedical research in our lifetime. "

Sir Paul Nurse, Cancer Research UK

Your research papers will be:

- available free of charge to the entire biomedical community

- peer reviewed and published immediately upon acceptance

- cited in PubMed and archived on PubMed Central

- yours - you keep the copyright

Submit your manuscript here:

http://www.biomedcentral.com/info/publishing_adv.asp
BioMedcentral 